\section{OP-245 腎移植後の体水分量变化の検討}

\section{奈良県立医科大学泌尿器科}

米田 龍生, 桑田 真臣, 初鹿野 俊輔, 中井 靖, 山田 篤, 吉川 元清, 壬生 寿一, 坂 宗久,

高尾 雅也, 石橋 道男, 藤本 清秀, 吉田 克法, 平尾 佳彦

【緒言】腎移植は慢性腎脕病に対する根治的な治療法であり排泄による生体 の恒常性維持に関して透析潦法よりすぐれている。腎移植後の体水分量法 免疫抑制剂や補液、急性尿細管壊死加らの利洜期など喠々の因子により修 飾される。今回、腎移植後の体水分量の変化について検討した。刘象・方 法]対象は、奈良県立医科大学で腎移植術を施行した患者 14 例（男性 9 例. 女性 5 例、平均年齢 $51.8 \pm 13$ 歳、生体腎 8 例 ·死体腎 6 例) で、In Body S20 (Biospace 社) を用いて電気インピーダンス法で体水分量を測定し、 術前後の変化について検討した。【結果】体水分量は、術前 $30.4 \pm 11.7$ 、術 後 1 週目 $32.3 \pm 12.1 、 2$ 週目 $31.9 \pm 14.2 、 3$ 週目 $26.3 \pm 9.3 、 4$ 週目 $27.0 \pm$ 9.4 であった。術前と比較して、細胞外液壮術後1 週目に高值を示寸が以降 は差を認めず、逆に細胞内液は3 週目までは差を認めなかったが、4 週目 に低值を示した。ほとめ腎移植直後は一過性に体水分量吕増加し、以降 徐々に低下し、4 调目には術前より低下する。術直後は主に細胞外液の変 動により体水分量は増加し、また安定期の体水分量低下は主に細胞内液の 減少によるものであった。電気インピーダンス法による体水分量測定は腎 移植後の水分管理に有用であることが示唆された。

\section{OP-246䁂移植患者における CKD の検討}

\author{
大阪市立大学大学院医学研究科泌尿器病態学 \\ 長沼 俊秀, 加藤 実, 西原 千香子, 出口 隆司, \\ 二宮 典子, 北本 興市郎, 岩井 友明, 内田 潤次, \\ 吉村 力勇, 武本 佳昭, 仲谷 達也
}

【背景】2002 年に米国 K/DOQIが初めて慢性腎脸病（CKD）の概念を 提唱して以来、2005 年にKDIGO (Kidney Disease : Improving Global Outcome) によって \#1.Stage5のうち透析療法を開始した患者を Stage5D とする、\#2、腎移植後の患者をその緊機能による分類に加えてTを付記す るの二点が追加され、国祭的にCKDの概念汃広く認識されるに至った。 そして、CKD が ESRD のリスクのみならずCVD の危険因子であること が明らかになり、CKD の早期発見と早期治療の重要性が認識されてきて いるが、腎移植患者に打り CKD に対する検討は少ない。【対象と方法] 安定した外来通院中の腎移植患者 89 名において通院中の腎移植患者 89 名 に打いて推定GFR 值 (MDRD GFR）及び微量アルブミン尿 (mg/gCre) を測定し、腎移植患者に㧍けるCKDのステージ分類を試みた。ついで、 CKD ステージとクリニカルパラメーター (年噛·性別·移植後年数・血圧. BNP等)の関保を検討した。結果】 1. 腎移植患者における CKD ステー 汾分類は、normal 2\%、CKD Stage2T 31.4\%、CKD Stage3T 58.8\%、CKD Stage4T 7.8\%であった。2. CKD stageの上昇とともにBNP 值も有意な 增加を示した。結語】腎移植患者にお斿るCKD の分類は Stage3T が最 も多かった。またＣKDはCVDに関伱している可能性が示された。

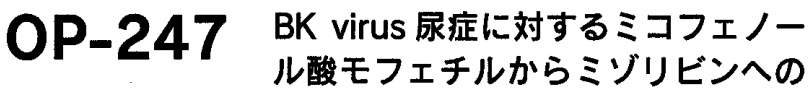 切替試験}

\author{
名古屋大学泌尿器科 ${ }^{1)}$ ，小牧市民病院 ${ }^{2)}$ ，岡崎市民病院 ${ }^{3)}$, \\ 成田記念病院 ${ }^{4)}$, 中京病院 ${ }^{5)}$ \\ 舟橋 康人 ${ }^{1)}$, 服部 良平 ${ }^{1)}$, 上平 修 ${ }^{2)}$, 松浦 治 ${ }^{2)}$, \\ 山田 伸 ${ }^{3)}$, 平林 聡 ${ }^{4)}$, 加藤 真史 ${ }^{5)}$, 絹川 常郎 ${ }^{5)}$, \\ 後藤 百万 $^{1)}$
}

【目的】免疫抑制療法における代謝拮抗剤としてミコフェノール酸モフェ チル (MMF)、ミゾリビン (MZ)、アザチオプリンがあるが、近年はより 強力な MMF が使用されることが多い。一方でMZ は免疫抑制効果だ忛 でなく抗 virus効果も報告されている。今回 MZ の BKVに対する効果 を検討するために、尿中 BKV 陽性例に対し MMF 加ら MZへの切替試 験を施行した。【方法】2005 年 4 月より維持免疫抑制寮法として MMF を使用している症例のうち、定量尿中 PCRにて BKV DNA 定量が 1.0 $\times 10^{2}$ copies $/ \mathrm{ml}$ 以上認めた 8 例を対象とした。移植後平均 20.0 个月 $(3$ 〜 40ケ月，、血清 Crl.6 $00.9 \mathrm{mg} / \mathrm{dl}$ であった。2 例で拒䋓反応の治療 歴があった。MMFを中止し MZを200mg/日から使用し、トラフ值が $0.5 \sim 1.0 \mu \mathrm{g} / \mathrm{ml}$ となるように維持した。観察期間は平均 10.1 ヶ月 (3〜 20ケ月)であった。結果】全症例に扩いて virus 量の減少を認め(平均 0.19 倍、中央值 $2.8 \times 10^{-3}$ 倍)、6 ケ月で 4 例、16 ケ月で 5 例において陰 性化した。な书拒絶反応を起こした症例はなく、切替後6ヶ月での血清 $\mathrm{Cr}$ は $1.5 \pm 0.9 \mathrm{mg} / \mathrm{dl}$ であった。結語】 MMF から MZへの切替により 尿中 BKV の減少ないし除性化を認め、MZの抗 BKV 効果が示唆された。

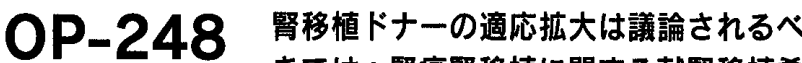 きでは：腎癌腎移植に関する献腎移植希 望登録者および透析患者の意識調查から}

国立病院機構長崎医療センター 泌尿器科 ${ }^{1)}$, 長崎大学 医学部菌学部附属病院泌尿器科 ${ }^{2)}$, 前田医院 ${ }^{3)}$, 黒木医 院 ${ }^{4)}$

松屋 福蔵 ${ }^{1)}$, 本田 真理子 ${ }^{1)}$, 志田 洋平 ${ }^{1)}$, 津田 聡 ${ }^{1)}$, 林 幹男 ${ }^{1)}$, 望月 保志 ${ }^{2)}$, 錦戸 雅春 ${ }^{2)}$, 前田 兼徳 ${ }^{3)}$, 前田 由紀 ${ }^{3)}$, 古賀 成彦 ${ }^{4)}$

腎移植の成績は向上し慢住腎不全の有力な治療法となっています汃、肝心の献腎移植

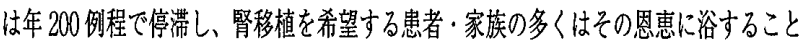
ができていません。病（気）腎移植は否定的な面はあるもののドナ一不足を補う第三 の道として医学的に可能性を秘好た間䞨です。しかし、その内容は非常にデリケート でらんなな意見があるのも事実です。ドナーの道底报大については、医学的妥当性の 检訪、社会の理解などが必要ですが、その前提となるのは腎移植を実際に受计る透析 患者さんがそれを希望する加否加です。今回、長崎県の献腎移植希望登録更新者（以 下、更新者）および一段の透析患者（以下、透析者）に対して、堅癌の場合に限定し た病（気）腎移植について希望度のアンケート諨查を行いました。坟象と方法] 具内 の更新者 74名（男47女27)、1 透析施設の透析者87名 (男56女31) にアンケート。 【結果】䑦刘に受计ないと否定したのは更新者で 32 名 (43\%)、透析者で 41 名 $(47 \%) 。$ 条件付希望を含的肯定的意見は更新者で 39 名 $(53 \%$ ）、透析者で 39 名 $(45 \%)$ 。はと

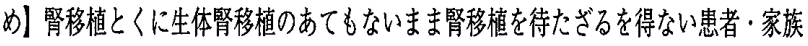

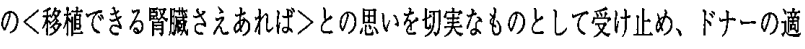

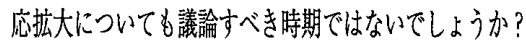

